Borneo Journal of Science \& Technology, Volume (2), Issue (2), Pages: 19-26

DOI: http://doi.org/10.3570/bjost.2020.2.2-04

e-ISSN: 2672-7439

(c) 2018, UCTS Publisher.

$\begin{array}{lll}\text { Submitted: } 01^{\text {st }} \text { May } 2020 & \text { Accepted: } 10^{\text {th }} \text { June } 2020 & \text { Published: } 31^{\text {th }} \text { July } 2020\end{array}$

\title{
Feasibility Study of Reinforced Concrete Beam with Embedded Polystyrene Spheres under Incremental Flexural Load
}

\author{
*Ji Wei Lau, Jen Hua Ling, and Yong Tat Lim \\ School of Engineering and Technology, University College of Technology Sarawak (UCTS), \\ 96000 Sibu, Sarawak, Malaysia
}

\begin{abstract}
The heavy weight of concrete, to some extent, imposes constraints on the design of reinforced concrete beams, particularly in the economic aspects. This could be overcome through partial replacement of concrete with lightweight materials in the elements. This study developed reinforced concrete beams with the embedment of polystyrene spheres and investigated their structural behaviour. Six specimens, including a control beam, were tested under incremental flexural load. All the specimens were tested until failure by using the Four-Point Load Test. The effects of the diameter and the spacing of the spheres on the structural response of the beams were studied. The loaddisplacement response, ultimate load, ultimate deflection, ductility, and crack patterns were analysed. The presence of the lightweight polystyrene spheres affected the structural response of the beam, particularly the strength and the ductility. With less than $9 \%$ concrete replacement, the ultimate strength and ductility decreased by $1.5 \%$ and $30 \%$ respectively, as compared with the control beam. The sphere is preferably in large diameter and closely spaced with each other for a higher percentage of concrete replacement and a higher degree of efficiency.
\end{abstract}

Keywords: Reinforced Concrete, Lightweight Materials, Flexural Load, Four-Point Load Test, Structural Response

\section{INTRODUCTION}

A Reinforced Concrete (RC) structure comprises the structural elements like beams, slabs, and columns. These elements form a skeletal frame system to sustain and transmit loads. For the reliability, durability and ease of construction, it is popularly used in Malaysia.

One of the challenges faced by the RC beam is the self-weight. The weight of the beam causes the span to be restricted within $9 \mathrm{~m}$. Subsequently, the structure becomes uneconomical.

The weight of RC beams can be reduced by removing some concrete in it. About $80 \%$ of the concrete in the tension zone is not utilised to carry load [1]. However, full removal can lead to a significant decrease of the load capacity [1].

For that, some concrete in RC beams was partially replaced by lightweight materials [2];[3]. It partially eliminates the ineffective concrete from the conventional $\mathrm{RC}$ beams by substituting the lightweight materials like plastic balls [2];[4], plastic bottles [5], Poly Vinyl Chloride pipe (PVC) [6]; [7].

This method can reduce the beam's weight by about $12 \%$ [8];[9];[10]. It enables a longer span of beams so that fewer columns are required in a structure [11]. This subsequently leads to saving in the construction cost.
This study aims to develop reinforced concrete beams with the embedment of polystyrene spheres. The polystyrene spheres could serve as void formers as their weight and strength in the element are often ignored during the analysis. In this study, six specimens, which were tested under incremental flexural load, were analysed for the structural behaviour and the feasibility.

\section{MATERIALS AND METHODS}

\section{Materials}

The materials used to fabricate the specimens included concrete, reinforcement bar, shear reinforcement, and polystyrene spheres (Table 1).

Table 1: Material specification

\begin{tabular}{ll}
\hline \multicolumn{1}{c}{ Material } & \multicolumn{1}{c}{ Description } \\
\hline Concrete & $\begin{array}{l}\text { Ready-mixed concrete, grade, } f_{c k}=25 \\
\text { N } / \mathrm{mm}^{2} \text { was used for casting. The designed } \\
\text { slump was between } 100 \mathrm{~mm} \text { and } 180 \mathrm{~mm} .\end{array}$ \\
\hline $\begin{array}{l}\text { Reinforcement } \\
\text { bar }\end{array}$ & $\begin{array}{l}\text { Steel grades, } f_{y k}=500 \mathrm{~N} / \mathrm{mm}^{2} \text { was used as } \\
\text { the top and bottom reinforcement bar. }\end{array}$ \\
\hline $\begin{array}{l}\text { Shear } \\
\text { reinforcement }\end{array}$ & $\begin{array}{l}\text { Steel grades, } f_{y k}=250 \mathrm{~N} / \mathrm{mm}^{2} \text { was used for } \\
\text { stirrups in beams. }\end{array}$ \\
\hline $\begin{array}{l}\text { Polystyrene } \\
\text { spheres }\end{array}$ & $\begin{array}{l}\text { The diameters were } 50 \mathrm{~mm}, 75 \mathrm{~mm} \text { and } \\
100 \mathrm{~mm} .\end{array}$ \\
\hline
\end{tabular}

Corresponding Author: Ji Wei Lau, University College of Technology Sarawak (UCTS),

E-mail: laujiwei@student.ucts.edu.my 


\section{Specimens}

One solid control beam and 5 beams with the embedment of polystyrene spheres were fabricated in the size of $1600 \mathrm{~mm}(\mathrm{~L}) \times 175 \mathrm{~mm}(\mathrm{~W}) \times 300 \mathrm{~mm}(\mathrm{H})$. The concrete cover was $25 \mathrm{~mm}$. The top and bottom reinforcements composed of two units of $10 \mathrm{~mm}$ and 12 $\mathrm{mm}$ diameters steel bars, respectively. The stirrups were $6 \mathrm{~mm}$ diameter spaced at $150 \mathrm{~mm}$ (Figure 1).
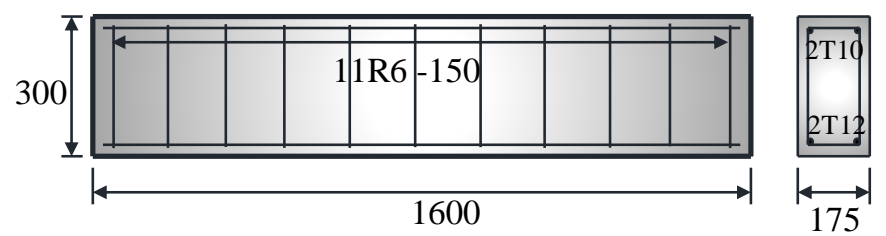

Figure 1: Reinforcement details of specimens

The polystyrene spheres in the diameter of $50 \mathrm{~mm}$, $75 \mathrm{~mm}$ and $100 \mathrm{~mm}$ were spaced at $10 \mathrm{~mm}, 20 \mathrm{~mm}$ and $30 \mathrm{~mm}$ (Table 2). They were positioned at the midheight of the specimens (Figure 2).
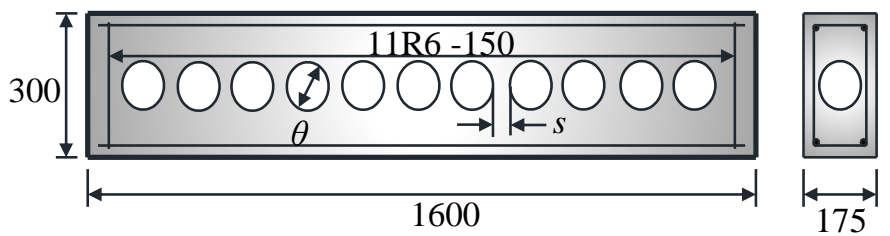

Figure 2: Alignment of polystyrene spheres in beam specimens

Table 2: Details of tested specimens

\begin{tabular}{ccccc}
\hline Specimen & $\begin{array}{c}\theta \\
(\mathrm{mm})\end{array}$ & $\begin{array}{c}s \\
(\mathrm{~mm})\end{array}$ & $\begin{array}{c}\text { Number } \\
\text { of } \\
\text { sphere, } n\end{array}$ & $\begin{array}{c}\text { Concrete } \\
\text { replacement, } \\
\%\end{array}$ \\
\hline BP 1 & 50 & 10 & 25 & 1.9 \\
\hline BP 2 & 75 & 10 & 18 & 4.7 \\
\hline BP 3 & 100 & 10 & 14 & 8.7 \\
\hline BP 4 & 100 & 20 & 12 & 7.5 \\
\hline BP 5 & 100 & 30 & 11 & 6.9 \\
\hline
\end{tabular}

Note: $\mathrm{BP}=$ Beam with embedded polystyrene spheres

The formworks of the specimens were made of the plywood and hardwood. Then, spheres were tied to the steel reinforcements at the intended locations by using galvanised wires before casting. The specimens were cured for 28 days prior to testing.

\section{Experimental setup}

The specimens were tested under the four-point load test. A hydraulic jack with a capacity of $300 \mathrm{kN}$ was used to impose force on a distribution beam, which transmitted the force to two steel rockers sitting on the specimens.
The distance between the rockers was $260 \mathrm{~mm}$ centre-tocentre while the effective span between supports was $1500 \mathrm{~mm}$ (Figure 3).

A load cell, three Linear Variable Differential Transformers, LVDTs and a data logger were used for data acquisition (Table 3). The load cell was placed between the hydraulic jack and the distribution beam to measure the load. An LVDT was placed at the mid-span of the specimens while another two were positioned directly below the point loads applied to the specimens.

The data logger was connected to a computer to monitor the load-displacement response in real-time. The load and the mid-span deflections were recorded and displayed on the computer during the testing.

Table 3: Details of the equipment used

\begin{tabular}{|c|c|c|c|}
\hline No & Equipment & Model & Capacity \\
\hline 1. & $\begin{array}{l}\text { Hydraulic } \\
\text { Jack }\end{array}$ & $\begin{array}{l}\text { ENEROAC RR- } \\
10018\end{array}$ & $\begin{array}{l}500 \mathrm{kN} \\
\text { capacity }\end{array}$ \\
\hline 2. & $\begin{array}{l}\text { Hydraulic } \\
\text { Pump }\end{array}$ & $\begin{array}{l}\text { Enerpac P-462 } 2 \\
\text { Speed Steel } \\
\text { Hand Pump }\end{array}$ & $\begin{array}{l}490 \mathrm{kN} \\
\text { Maximum } \\
\text { Handle Effort }\end{array}$ \\
\hline 3. & LVDT & CDP-100 & $\begin{array}{l}\text { Stroke } 50 \text { and } \\
100 \mathrm{~mm}\end{array}$ \\
\hline 4. & Load Cell & CLJ-300KNB & $\begin{array}{l}\text { Capacity } \\
\text { 300kN }\end{array}$ \\
\hline 5. & $\begin{array}{l}\text { Data } \\
\text { logger }\end{array}$ & TML TDS-630 & 50 Channels \\
\hline
\end{tabular}

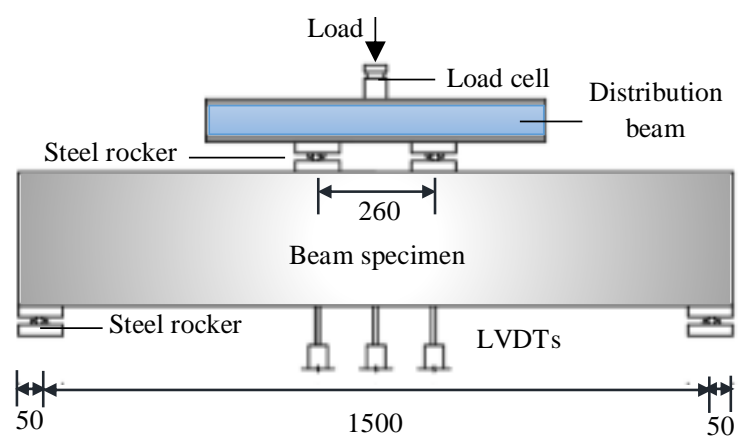

Figure 3: Typical experimental setup for Four-Point Flexural Test

\section{Testing Procedure}

Initially, the specimen was preloaded to $10 \%$ of the estimated ultimate capacity for about 5 minutes. The preload was then released for 1 minute to observe readings returned to zero. This procedure was repeated twice to ensure the good conditions of the measuring devices.

After that, the LVDTs and the load cell were reinitialised to zero before starting the test. Before taking the reading, the loading was held for at least 1 minute. During the elastic stage, the load was gradually increased 
at an interval of about $5 \mathrm{kN}$. After yielding, the reading was recorded at every $0.5 \mathrm{~mm}$ displacement.

During the testing, the propagation of the crack on the beam surface was monitored. The test stopped after the five consecutive drops of the readings given by the load cell. Lastly, the ultimate strength, the deflection, and the mode of failure were recorded.

\section{RESULTS AND DISCUSSION}

\section{Material properties}

On the testing day of the beam specimen, two concrete cubes $(150 \mathrm{~mm} \times 150 \mathrm{~mm} \times 150 \mathrm{~mm})$ were tested in accordance with BS EN 12390-3:2009. The average value of the compressive strength represented the concrete strength of the specimen. Generally, the concrete strengths were close to the desired strength of $25 \mathrm{~N} / \mathrm{mm}^{2}$ (Table 4).

Table 4: Compressive strength of concrete

\begin{tabular}{|c|c|c|c|}
\hline \multirow[t]{2}{*}{ Specimen } & \multicolumn{2}{|c|}{$f_{c u}\left(\mathrm{~N} / \mathrm{mm}^{2}\right)$} & \multirow{2}{*}{$\begin{array}{c}f_{c u, a v g} \\
\left(\mathrm{~N} / \mathrm{mm}^{2}\right)\end{array}$} \\
\hline & Cube 1 & Cube 2 & \\
\hline CB 1 & 26.1 & 26.5 & 26.3 \\
\hline BP 1 & 26.8 & 27.3 & 27.1 \\
\hline BP 2 & 26.6 & 27.1 & 26.9 \\
\hline BP 3 & 26.3 & 26.9 & 26.6 \\
\hline BP 4 & 26.6 & 27.4 & 27.0 \\
\hline BP 5 & 26.6 & 26.8 & 26.7 \\
\hline
\end{tabular}

Note: $f_{c u}=$ Compressive strength value, $f_{c u, a v g}=$ Average compressive strength value

The tensile test was also conducted on three steel bars based on BS EN ISO 6892-1:2016. The bar strengths were greater than their nominal strength of 500 $\mathrm{N} / \mathrm{mm}^{2}$ and $250 \mathrm{~N} / \mathrm{mm}^{2}$ (Table 5).

The material strengths were quite consistent and were all higher than the required strength. Thus, the material's quality was considered acceptable.

Table 5: Tensile strength of steel bar

\begin{tabular}{ccccc}
\hline $\begin{array}{c}\text { Bar } \\
\text { Diameter, } \\
\text { mm }\end{array}$ & \multicolumn{3}{c}{$\begin{array}{c}\text { Tensile Strength, } \boldsymbol{f}_{\text {s.c }} \\
\left(\mathbf{N} / \mathbf{m m}^{\mathbf{2}}\right)\end{array}$} & $\begin{array}{c}\boldsymbol{f}_{\text {s,u,avg }} \\
\left(\mathbf{N} / \mathbf{m m}^{\mathbf{2}}\right)\end{array}$ \\
\cline { 2 - 4 } & $\mathbf{S 1}$ & $\mathbf{S 2}$ & $\mathbf{S 3}$ & \\
\hline $\mathbf{6}$ & 290 & 279 & 285 & 284.7 \\
\hline $\mathbf{1 0}$ & 590 & 640 & 635 & 621.7 \\
\hline $\mathbf{1 2}$ & 670 & 660 & 650 & 660.0 \\
\hline
\end{tabular}

Note: $f_{s, u}=$ Tensile Strength Value, $f_{s, u, \text { avg }}=$ Average Tensile Strength Value

\section{Load-Displacement Response}

Initially, the specimens gave a high degree of stiffness, as presented by the slope of the load-displacement curve (Figure 4). The deflection generated was proportional to the load applied.

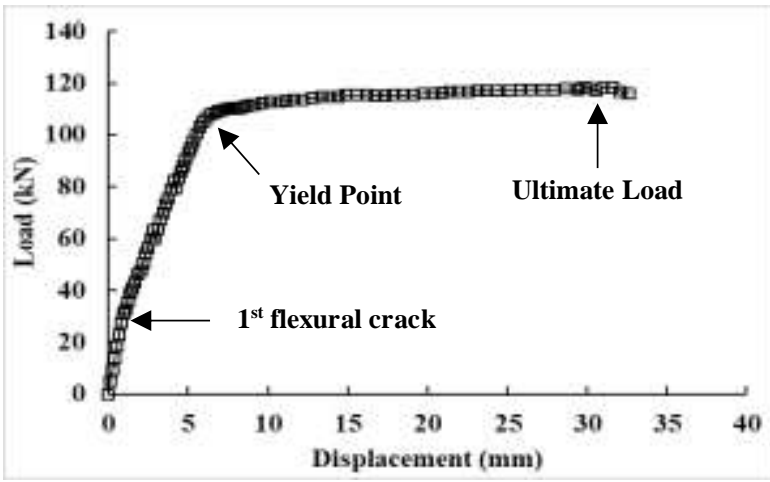

(a) CB 1

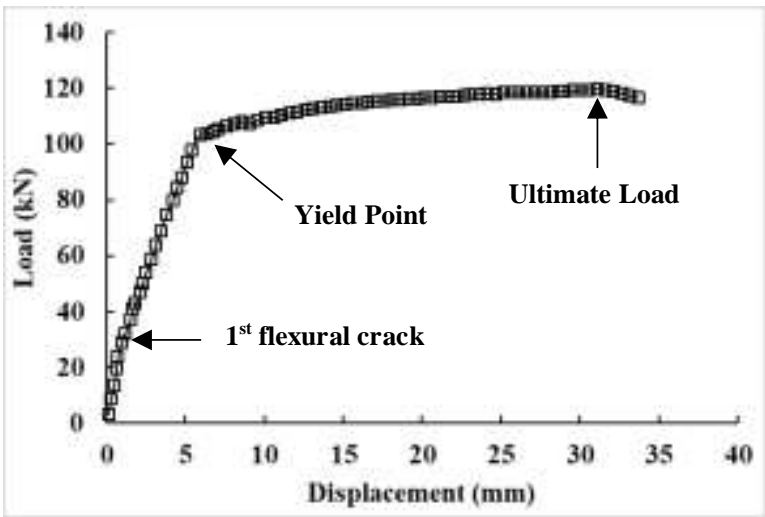

(b) BP 1

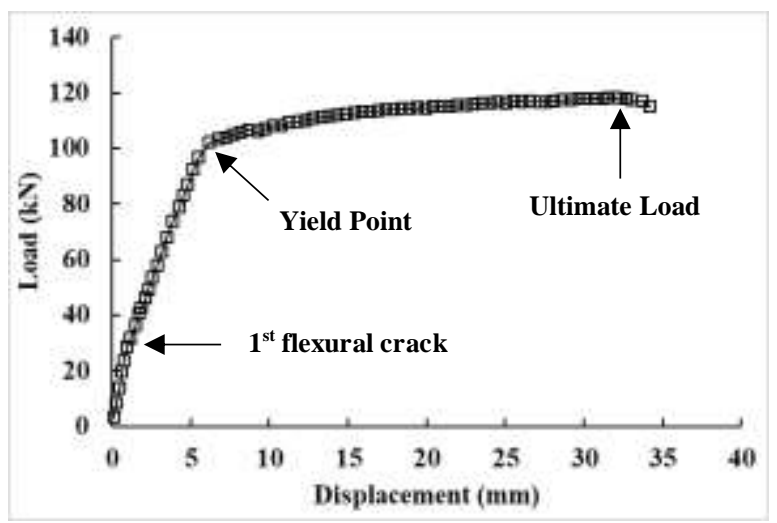

(c) BP 2

Figure 4: Load-displacement curves of specimens 


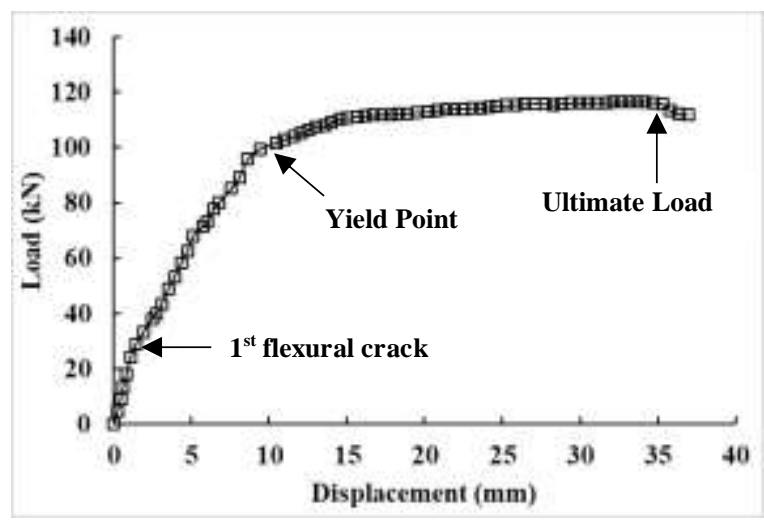

(d) BP 3

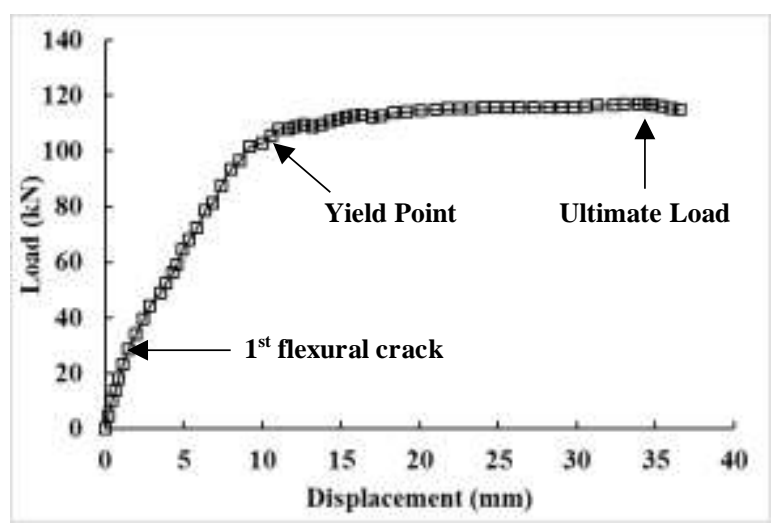

(e) BP 4

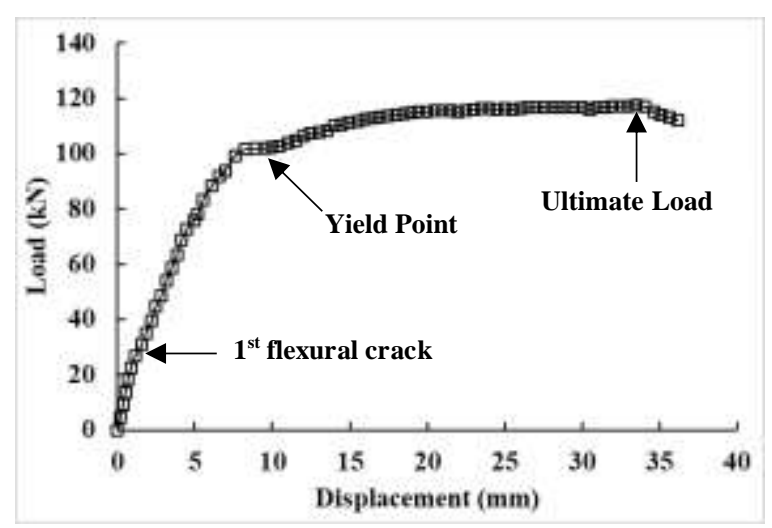

(f) BP 5

Figure 4: Load-displacement curves of specimens (Continued)

The first flexural crack occurred around $30 \mathrm{kN}$ load $(\approx 1 / 4$ ultimate load). It occurred when the tensile stress of concrete exceeded its modulus of rupture. It developed at the mid-span, and caused the deflection to develop at a faster rate, and thus, resulted in a slight reduction of the stiffness. As the reinforcement bars were yet to yield, the specimen response was still elastic.
The specimen yielded around $100 \mathrm{kN}$ load. Due to the yielding of steel reinforcement and excessive cracks of concrete, the specimen lost elasticity and underwent plastic deformation. At this stage, the stiffness decreased dramatically, and considerable displacement was observed over a slight increase of load until the specimens experienced flexural failure and lost its ability to sustain load at the ultimate state

\section{Load Capacities}

The experimental results for the specimens were analysed in term of the first crack load $\left(P_{c r}\right)$, yield load $\left(P_{y}\right)$, and ultimate load $\left(P_{u}\right)$, as tabulated in Table 6.

Table 6: Experimental results

\begin{tabular}{cccc}
\hline Specimens & $P_{c r}(\mathrm{kN})$ & $P_{y}(\mathrm{kN})$ & $P_{u}(\mathrm{kN})$ \\
\hline CB 1 & 31.0 & 108.2 & 118.4 \\
\hline BP 1 & 29.0 & 104.6 & 119.8 \\
\hline BP 2 & 31.7 & 103.3 & 118.3 \\
\hline BP 3 & 33.5 & 101.7 & 116.7 \\
\hline BP 4 & 34.0 & 103.0 & 117.0 \\
\hline BP 5 & 34.9 & 101.4 & 117.4 \\
\hline
\end{tabular}

The presence of polystyrene spheres slightly affected the ultimate strength of the beams. Compared with the solid beam, the ultimate strength for the beam specimens with embedded polystyrene spheres varied between $0.1 \%$ and $1.5 \%$.

Specimen BP 1 recorded the highest ultimate strength. For (a) the lowest replacement volume of concrete (1.9\%) and (b) the highest number of spheres in the concrete, which led to more spacing gaps between the sphere (concrete ribs) in the beam, the specimens offered the highest strength. The ribs enabled an effective distribution of stresses in the beam, thus improved its structural performance. This was in-line with the findings by Lim and Ling [12].

The effect of the sphere's diameter was demonstrated by specimens BP 1,2 , and 3 with the same spacing. The ultimate strength of the beam specimens decreased by $2.7 \%$ as the diameter increased from 50 $\mathrm{mm}$ to $100 \mathrm{~mm}$. Large spherical diameter reduced the cross-section area (Table 7) and thus effected the ultimate strength of the beam (Figure 5). This was in-line with the findings by Izzat $e t$. al, [13]. 
Table 7: Details of variation in diameter and reduction in cross- sectional area

\begin{tabular}{ccccc}
\hline Specimen & $\begin{array}{c}\emptyset \\
(\mathrm{mm})\end{array}$ & $\begin{array}{c}A_{v} \\
\left(\mathrm{~mm}^{2}\right)\end{array}$ & $\begin{array}{c}A_{b} \\
\left(\mathrm{~mm}^{2}\right)\end{array}$ & $A_{R}(\%)$ \\
\hline BP 1 & 50 & 1963.50 & 52500 & 3.7 \\
\hline BP 2 & 75 & 4417.86 & 52500 & 8.4 \\
\hline BP 3 & 100 & 7853.98 & 52500 & 15.0 \\
\hline
\end{tabular}

Note: $\varnothing=$ Diameter of polystyrene spheres, $A_{v}=$ Area of polystyrene spheres, $A_{b}=$ Cross-Sectional Area of solid beam, $A_{R}$ Percentage of reduction in the cross-sectional area of the beam

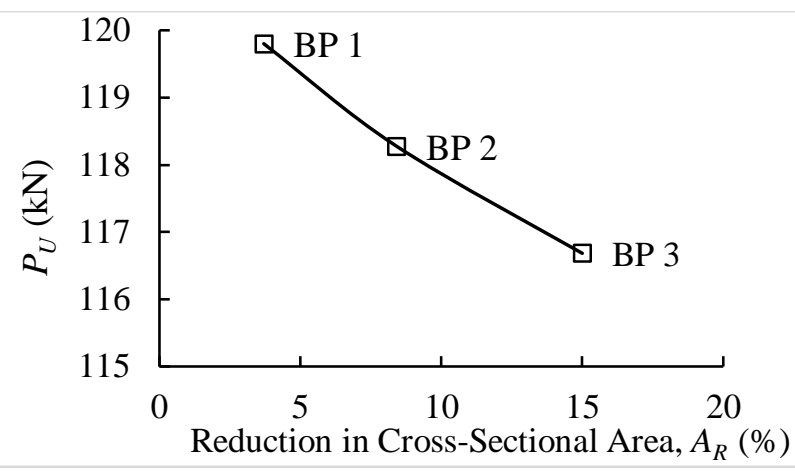

Figure 5: Change in $P_{U}$ with respect to $A_{R}$

The effects of the spacing between spheres, $\mathrm{S}$ were observed from BP 3, 4 and 5 with the same sphere's diameter. The ultimate strength increased as the spacing increased from $10 \mathrm{~mm}$ to $30 \mathrm{~mm}$ (Figure 6). The closeto-linear relationship between the ultimate load and the spacing implied a strong correlation between the two parameters.

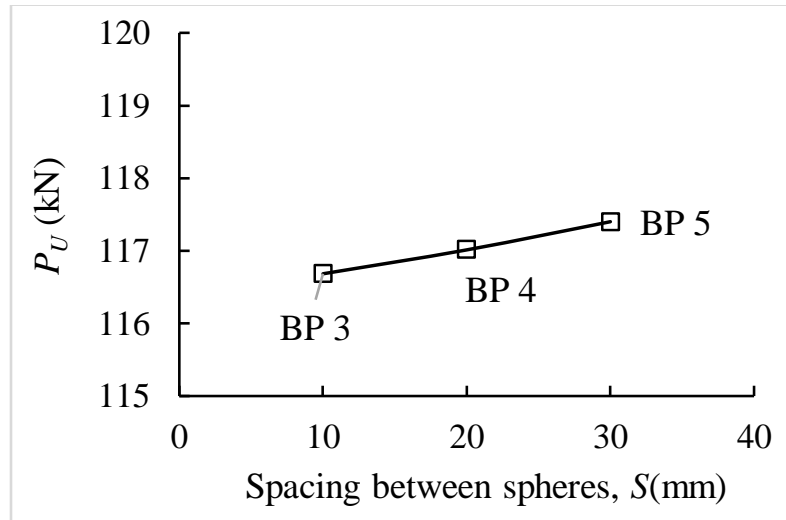

Figure 6: Change in $P_{U}$ with respect to $S$

When the spacing between polystyrene spheres increased from $10 \mathrm{~mm}$ to $30 \mathrm{~mm}$, the ultimate strength increased by $0.6 \%$, from $116.7 \mathrm{kN}$ to $117.4 \mathrm{kN}$. It could also due to the slight change in the volume of concrete replacement, from $8.7 \%$ to $6.9 \%$.

\section{Crack Pattern}

At the initial stages of loading, all the specimens remained un-cracked. As the load reached the rupture strength of the concrete, the concrete started to crack. The crack patterns of the specimens were displayed in the Figure 7.

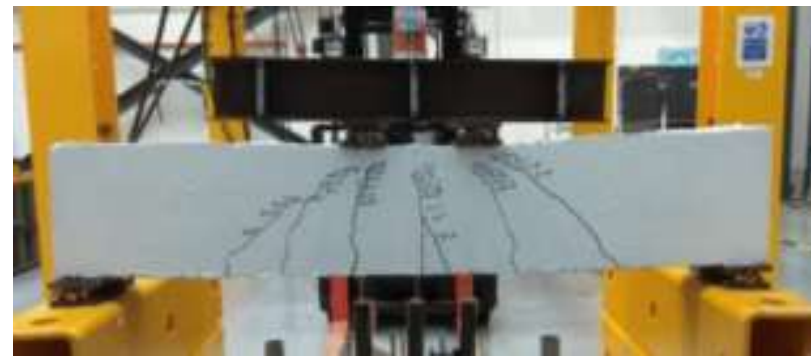

(a) Specimen CB 1

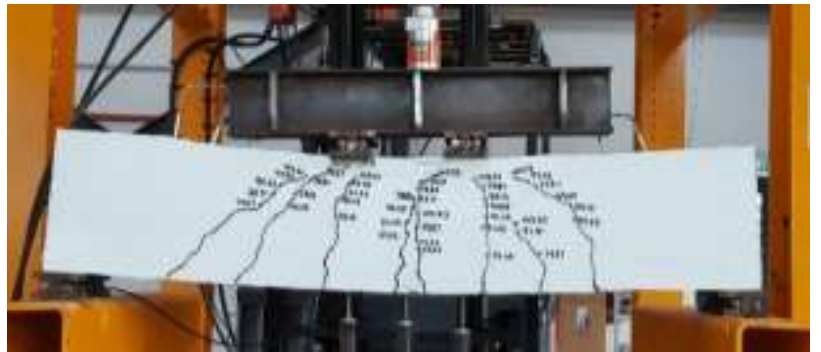

(b) Specimen BP 1

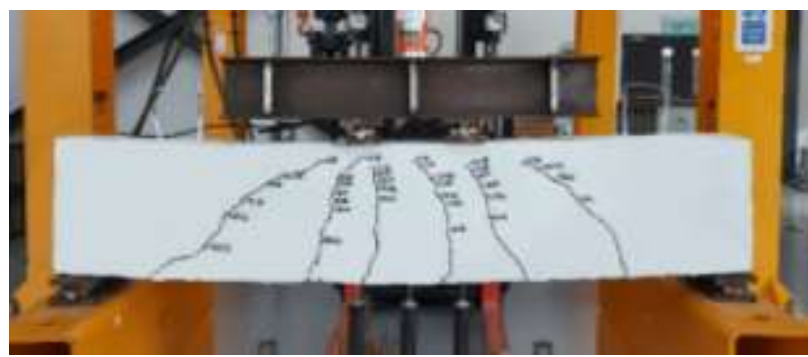

(b) Specimen BP 2

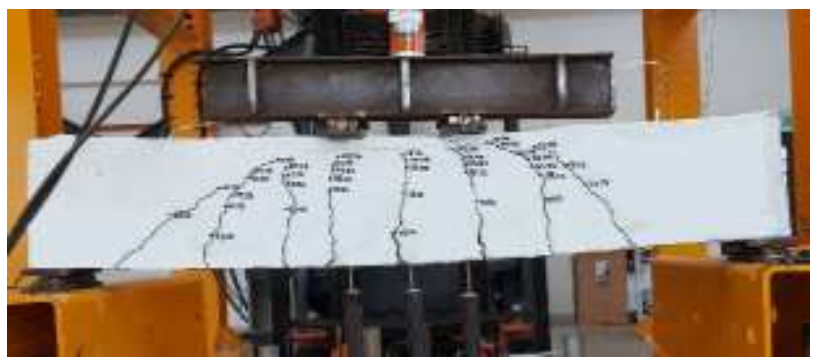

(c) Specimen BP 3

Figure 7:Crack Pattern of Specimens 


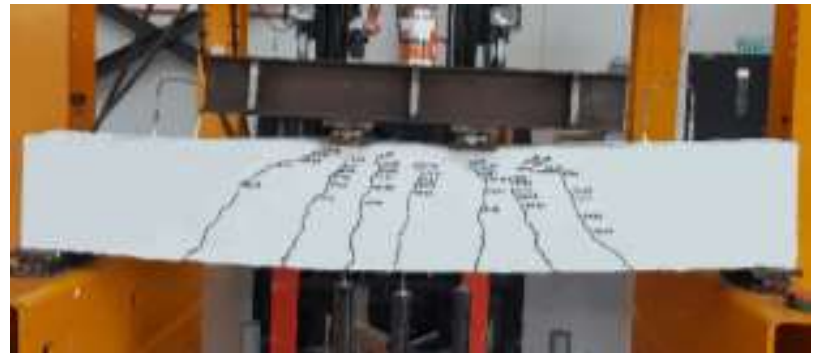

(d) Specimen BP 4

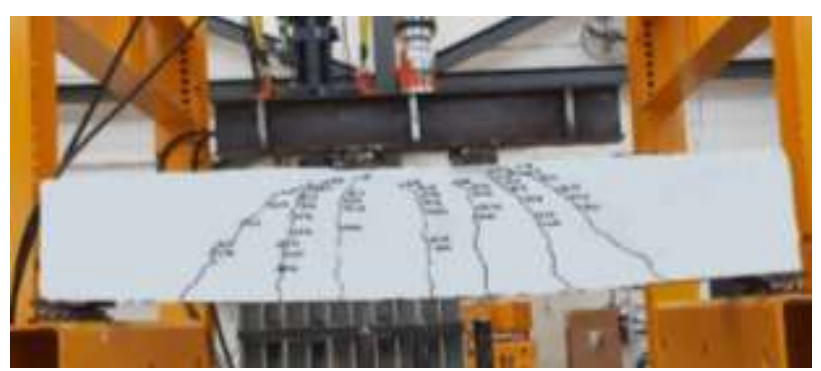

(e) Specimen BP 5

Figure 7: Crack Pattern of Specimens (Continued)

Initially, the first crack developed at the mid-span of the beams. These cracks were formed at $24.2 \%$ to $28.7 \%$ of the ultimate load. Then, it began to propagate upwards to the loading points. As the load increased further, more cracks appeared and diagonal cracks were observed.

The cracks extended and widened as the load increased. They deteriorated the concrete, degraded the bond performance between the concrete and the reinforcements, and affected the load resisting ability of the beam.

Most of the beam specimens experienced flexural failure except for BP 2 and BP 3 which underwent flexural-shear failure. The appearance of inclined diagonal shear crack that propagated from the support towards the loading point could be observed from these two specimens. The large diameter of the polystyrene sphere caused the specimens more susceptible to flexural-shear failure.

\section{Ductility}

The ductility of the beams resembled its ability to withstand deformation beyond the elastic limit before the failure of the beam. It is expressed in a dimensionless factor, $\mu=\delta_{u} / \delta_{y}$, where $\delta_{u}$ and $\delta_{y}$ are the ultimate and yield deflections, respectively (Table 8 ).
Table 8: Ductility properties of specimen

\begin{tabular}{cccc}
\hline Specimens & $\delta_{y}(\mathrm{~mm})$ & $\delta_{u}(\mathrm{~mm})$ & $\mu=\delta_{u} / \delta_{y}$ \\
\hline CB 1 & 6.43 & 30.02 & 4.67 \\
\hline BP 1 & 6.77 & 31.12 & 4.60 \\
\hline BP 2 & 6.81 & 31.55 & 4.63 \\
\hline BP 3 & 10.45 & 34.15 & 3.27 \\
\hline BP 4 & 10.02 & 33.97 & 3.39 \\
\hline BP 5 & 8.23 & 33.49 & 4.07
\end{tabular}

Note: $\delta_{y}=$ Yield displacement; $\delta_{u}=$ Ultimate displacement; $P_{u}$

As compared with the solid beam, the $\mu$ for the beams with polystyrene spheres embedded decreased $0.9 \%$ to $30.0 \%$. The trend of $\mu$ was scattered as a slight change in terms of the load-displacement curve could result in a relatively significant change of $\mu$. It was very much governed by the yield displacement. When the yield displacement was relatively small, even though the ultimate displacement was about similar, the ductility could differ quite significantly.

For that, $\mu$ is normally used to indicate the degree of ductility rather than measuring it. The results indicated a lower ductility is because of higher yield displacement of the beam specimens. For a low moderate region, $\mu$ is preferably been greater than 4.0 [14].

Nevertheless, the effect of beams' ductility could be statistically analysed by correlating it with the volume of concrete replacement (Figure 8). It reduced as the concrete replacement increased. This was attributed to a lower degree of stiffness caused by the concrete replacement, which resulted in a larger yield displacement, and subsequently led to lower ductility of the specimen.

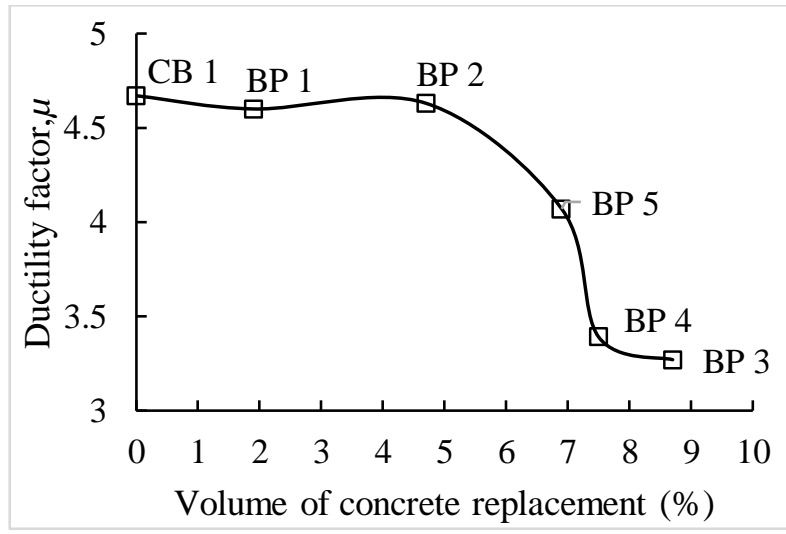

Figure 8: Ductility, $\mu$, vs the percentage of volume replacement in beam specimens 


\section{Feasibility Assessment}

Table 9 evaluates the feasibility of the specimens. The load ratio, $P_{R}$, indicates the ratio of the ultimate strength of beam specimens with polystyrene spheres to the control beam. The volume ratio, $V_{R}$, divides the volume of the beam specimens with polystyrene spheres by the solid beam.

Table 9: Feasibility evaluation criteria

\begin{tabular}{cccc}
\hline Specimens & $\begin{array}{c}\text { Load Ratio, } \\
P_{R}=P_{u, i} / P_{u, c}\end{array}$ & $\begin{array}{c}\text { Volume, } \\
V_{R}=V_{i} / V_{c}\end{array}$ & $P_{R} / V_{R}$ \\
\hline BP 1 & 1.011 & 0.981 & 1.03 \\
\hline BP 2 & 0.999 & 0.953 & 1.05 \\
\hline BP 3 & 0.987 & 0.913 & 1.08 \\
\hline BP 4 & 0.988 & 0.925 & 1.07 \\
\hline BP 5 & 0.991 & 0.931 & 1.06 \\
\hline
\end{tabular}

Note: $P_{u, i}$ and $\delta_{u, i}$ are the ultimate strength and displacement of the beam specimens with embedded polystyrene spheres respectively, meanwhile, $P_{u, c}$ and $\delta_{u, c}$ represent the control specimen.

The feasibility of the specimens was analysed based on the effective strength to volume ratio, $P_{R} / V_{R}$. The specimen was considered feasible when the ratio was more than 1, which means the reduction of concrete volume (beam's weight) exceeded the loss of strength, in percentage.

All specimens had the $P_{R} / V_{R}$ ratio greater than 1.0. Thus, all the beam specimens were all considered feasible. The polystyrene spheres had effectively reduced the beam's weight without significantly affecting the beam's strength.

Among all, BP 3 yielded the best efficiency. Its $P_{R} / V_{R}$ ratio was the greatest and the strength per unit concrete volume was the highest.

\section{CONCLUSION}

In this study, polystyrene spheres were embedded in reinforced concrete beams to reduce its self-weight. The structural behaviour of the beam specimens with polystyrene spheres has been studied experimentally.

From the test results, the followings are concluded:

a) The polystyrene spheres in the reinforced concrete beam affected its ultimate strength and ductility. With the concrete replacement of less than 9\%, the ultimate strength varies between $0.1 \%$ and $1.5 \%$ while the ductility varies between $0.9 \%$ and $30 \%$ as compared with the solid beam. For high strength and ductility, low replacement of concrete is preferred.

b) The diameter and the spacing between the spheres affected the structural response of the beam. As the diameter increased from $50 \mathrm{~mm}$ to $100 \mathrm{~mm}$, the ultimate strength reduced by $2.7 \%$. On the contrary, an increase of the spacing from $10 \mathrm{~mm}$ to $30 \mathrm{~mm}$ reduced the ultimate capacity by $0.6 \%$.

c) The beam specimens were evaluated for the feasibility by using the effective strength to volume ratio, $P_{R} / V_{R}$. BP 3 with the largest sphere diameter $(100 \mathrm{~mm})$ and smaller spacing $(10 \mathrm{~mm})$ was found offering the highest strength per unit concrete volume among the specimens tested.

At the current stage of exploratory, the emphasis was to determine the feasibility of embedding polystyrene spheres in the reinforced concrete beam to reduce the weight of the member and increase its efficiency. Such beams were fabricated and tested in the laboratory to determine if the beam is fabricate-able. Both aspects demonstrated positive outcomes.

Nevertheless, numerous technical challenges may need to be overcome, some of which are:

a) Low cover of concrete due to the embedment of polystyrene spheres may affect the bond performance of the main and shear reinforcements, stress-strain properties, creep resistance, and probably the impact resistance of the concrete.

b) Replacement of concrete by polystyrene sphere near the regions of high shear load, such as the supports, may affect the shear strength of the beam, and possibly lead to brittle failure.

c) The techniques of fabrication, such as production, placing, and positioning of the polystyrene sphere within the limited space between the reinforcements of the beam, particularly when the beam is heavily reinforced, may need to be further optimized. future.

These could be good areas to be studied in the

\section{ACKNOWLEDGEMENT}

The author gratefully thanks for financial support under the research grant UCTS/ RESEARCH/2/2018/02.

\section{REFERENCES}

[1] Ali, S. and Kumar, M. 2017. Analytical Study of Conventional Slab and Bubble Deck Slab Under Various Support and Loading Conditions Using Ansys Workbench 14.0. International Research Journal of Engineering and Technology, 4(5), 14671472.

[2] Sivaneshan, P. and Harishankar, S. 2017. Experimental Study on Voided Reinforced Concrete Beams with Polythene Balls. In: IOP Conference Series: Earth and Environmental Science, 6-8 October 2017, Cyprus. Famagusta: IOP Publishing, 1-8. 
[3] Kumar, A.S. and Joy, A. 2013. Experimental Investigation on Partial Replacement of Concrete Below Neutral Axis of Beam. International Journal of Science and Research, 2(8), $1670-1674$.

[4] Soman, S. and Anima, P. 2016. Experimental and Analytical Investigation on Partial Replacement of Concrete in the Tension Zone. International Journal of Engineering Research and General Science, 4(4), $23-32$.

[5] Mathew, I. and Varghese, S.M. 2016. Experimental Study on Partial Replacement of Concrete in and Below Neutral Axis of Beam. International Journal of Innovative Research in Technology, 3(4), 188 192.

[6] Parthiban, N. and Neelamegam, M. 2017. Flexural Behviour of Reinforced Concrete Beam with Hollow Core in Shear Section. International Research Journal of Engineering and Technology, 4(4), $2263-2273$.

[7] Dhinesh, N.P., and Satheesh, V.S. 2017. Flexural Behaviour of Hollow Square Beam. International Journal of Scientific Engineering and Applied Science, 3(3), 236 - 242.

[8] John, R. and Varghese, J. 2015. A study on behavior of bubble deck slab using ansys. International Journal of Innovative Science, Engineering \& Technology, 2(11), $560-563$.
[9] Manikandan, S., Dharnar, S. and Robertravi, S. 2015. Experimental Study on Flexural Behaviour ofReinforced Concrete Hollow Core Sandwich Beams. International Journal of Advance Research in Science and Engineering, 4 (1), 937 - 946.

[10] Arati, S. and Nagesh,H. 2015. An Experimental Study On Bubble Deck Slab System with Elliptical Balls, 12(1), 21-27.

[11]Bubble Deck Construction Sdn Bhd. 2018. Bubble Deck FAQ. [Online] Available at: <https://bubbledeck.com.my/reference-faq.html> [Accessed February 3, 2018].

[12]Lim, Y.T. \& Ling, J.H. 2019. Incorporating Lightweight Materials in Reinforced Concrete Beams and Slabs - A Review. Borneo Journal of Sciences and Technology, 1(2), 16-26.

[13] Izzat, A.F, Farhan, J.A, and Allawi, N.M. 2014. Behaviour and Strength of One Way Reinforced Concrete Slabs with Cavities. International Conference for Engineering Science, University of Mustansiriyah, Baghdad, Iraq, 100-115

[14] Ling, J.H., Abd. Rahman, A.B., Ibrahim, I.S., Abdul Hamid, Z. 2017. An Experimental Study of Welded Bar Sleeve Wall Panel Connection under Tensile, Shear, and Flexural Loads. International Journal of Concrete Structures and Materials, 11(3), 525-540. 